\title{
Immediate post-extraction implants subject to immediate loading: A meta-analytic study
}

\author{
Carmen Enríquez-Sacristán ${ }^{1}$, Cristina Barona-Dorado ${ }^{2}$, José-Luis Calvo-Guirado ${ }^{3}$, Isabel Leco-Berrocal ${ }^{4}$, \\ José-Ma Martínez-González ${ }^{5}$
}

${ }^{1}$ Dentist. Masters in Oral Surgery and Implantology at the University Hospital of Madrid

${ }^{2}$ Associate Professor of Surgery. School of Dentistry. Complutense University of Madrid. Assistant Director of the Masters program in Oral Surgery and Implantology. University Hospital of Madrid

${ }^{3}$ Acting Professor of Integrated Adult Dentistry. School of Medicine. University of Murcia

${ }^{4}$ Associate Professor of Surgery. School of Dentistry. Complutense University of Madrid. Professor of the Masters program in Oral Surgery and Implantology. University Hospital of Madrid

${ }^{5}$ Professor of Maxillofacial Surgery. School of Dentistry. Complutense University of Madrid. Department Chief of Oral Surgery and Implantology. University Hospital of Madrid

Correspondence:

Department of Medicine Oral and Maxillofacial Surgery, School of Dentistry. Complutense University of Madrid,

Plaza Ramón y Cajal, s/n Madrid

crisbarona@hotmail.com

Received: 02/03/2010

Accepted: 14/11/2010
Enríquez-Sacristán C, Barona-Dorado C, Calvo-Guirado JL, Leco-Berrocal I, Martínez-González JM. Immediate post-extraction implants subject to immediate loading: A meta-analytic study. Med Oral Patol Oral Cir Bucal. 2011 Nov 1;16 (7):e919-24.

http://www.medicinaoral.com/medoralfree01/v16i7/medoralv16i7p919.pdf

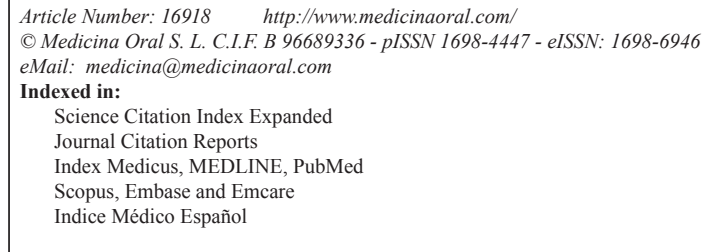

\begin{abstract}
Since Brånemark first started developing its implant system, there has been a continuous and significant evolution in oral implantology through experimental and clinical research, and many of the concepts that were once considered valid have now become the subject of debate. The insertion of the implant immediately after extraction of the tooth to be substituted has now become the implant treatment of choice and is associated with preserving the bone structure and the gingival architecture, as well as with reducing the treatment time, which ultimately benefits the patient.

Objective: To evaluate the success rate of the immediate post-extraction implants (IPI) subject to immediate loading. Study Design: A meta-analytic study was carried out on 659 immediate post-extraction implants obtained from a bibliographic review of 25 articles published within the last 9 years.

Results: We obtained a sample of 322 patients who had been treated with a total of 659 implants placed immediately following extraction. The mean age of the patients was 51 years old. A total of 441 implants were inserted in the maxilla, 152 in the mandible and 64 were placed in an unspecified location. The survival rate ranged between $85 \%$ and $100 \%$.

Conclusions: Immediate post-extraction implant treatment is an implant alternative with a survival rate similar to that of the conventional technique for implant placement and enables preserving both the bone structure and gingival architecture, as well as providing immediate functional loading, thus improving the quality of the treatment as far as the patient is concerned.
\end{abstract}

Key words: Immediate post-extraction implant, immediate loading, survival rate. 


\section{Introduction}

The placement of the implant in a post-extraction bed is a technique that has been developed, especially within the last 10 years, although in as early as the 1980s at the University of Tübingen, an implant model was designed in order to substitute the extracted tooth during the same surgical procedure, thus introducing the concept of immediate post-extraction implants (1).

The primary needs that have led to introducing this protocol are due to the patients' demand to reduce the therapy time, but above all due to the need to preserve the alveolar structures that are intended for the reabsorption process following extraction of the tooth (2). Following tooth avulsion, there are a series of biological processes that take place: bone reabsorption both vertically as well as horizontally, with a change in the height and thickness of the alveolar bone; gingival collapse; migratory movements of the adjacent teeth; modification of the bone quality with a collapse of the compact bone and formation of alveolar bone marrow.

During the interval of time that passes between tooth avulsion and the placement of the implant, the majority of the amount of bone reabsorption and gingival remodeling is verified, which is usually the cause of biological, aesthetic and functional damage (3).

Once the process of remodeling the alveolus has been completed, the alveolus is unlikely to present an adequate diameter for the implant, thus sometimes hindering the possibility of implant treatment.

Due to all of these factors, the technique for placement of implants immediately after extraction was proposed as a way of maintaining the osseous substrate of the surgical area.

\section{Material and Method}

A search was carried out in PUBMED on articles published between January 2000 and May 2009 on immediate post-extraction implants subject to immediate loading. The keywords used were "immediate implant placement" and "immediate loading".

The inclusion criteria for the meta-analytic study of the articles was to specify the number and the survival rate of implants placed immediately following extraction and implants that were subject to immediate loading. A total of 25 articles were found with the keywords "immediate implant placement" and "immediate loading". We selected 13 articles that fulfilled all of the inclusion criteria.

The data obtained was included in a table in which the following variables were analyzed: author, number of patients, gender, mean age, number of implants placed, type of implants, if a flap was made, if the leftover space was filled (GAP), if the prosthesis was functional, the location of the implant, the insertion torque, type of provisional and permanent prosthesis, and the success rate obtained (Table 1). A second table was also made (Table 2) in which the number of failed implants were studied, indicating where they were located (maxilla or mandible), when the possible cause took place and the treatment that was considered to be suitable.

\section{Results}

A sample of 322 patients was obtained (161 females, 104 males and 57 patients whose gender was not specified), with a mean age of 51 years old and who were treated with a total of 659 implants placed immediately following extraction.

A total of 441 implants were inserted in the maxilla, 152 in the mandible and 64 implants were placed in an unspecified location (Fig. 1).

In all of the cases, the extraction was carried out as atraumatically as possible, performing an odontosection in the premolars and upper molars, provided it was necessary, followed by a meticulous curettage of the alveolus.

Of the authors selected, some did not carry out detachment for the setting of 402 implants (2-6), compared to others who designed and made a flap for the drilling sequence (7-12) and subsequent placement of $257 \mathrm{im}-$ plants.

The leftover gap between the buccal plate and the implant surface was filled in with autogenous bone in 350 implants and with alloplastic material in 113 implants, whereas in 18 fixtures, it was preferred that the clot itself fill this space. In 178 implants, it was not evaluated whether the GAP was filled or not (Fig. 2).

The majority of the authors do not make any reference to the insertion torque $(2,5,8,9,10,11)$, only some $(3,4,6,7,12,13)$ specify that it ranged between $25-45 \mathrm{~N} /$ $\mathrm{cm}$ on a total of 378 implants.

All of the implants were rehabilitated at the time of the surgery, some temporarily and others permanently. In 82 of the cases, the purpose of the immediate loading was for aesthetic reasons, and in 432 patients, the implants also withstood the force of mastication. The authors concurred on this fact in a total of 145 implants (Fig. 3).

A total of 11 implants were considered to be failures, and the implant was thus removed. Five of such cases were due to pain and mobility, 2 were due to fracture of the platform, 1 due to poor bone quality, 2 due to lack of osseous integration and one due to periimplantitis with suppuration. With the exception of the 2 implants in which the platform was fractured, all of the rest failed within a few months of being placed and the location was similar for the maxilla and the mandible. In all of such cases, an explant was performed and a new implant was placed. In some cases the placement was immediate, whereas in others there was a waiting period. 


\begin{tabular}{|c|c|c|c|c|c|c|c|c|c|c|c|c|}
\hline 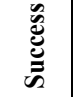 & \begin{tabular}{l} 
今े \\
$\vdots$ \\
\multirow{2}{0}{}
\end{tabular} & 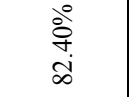 & 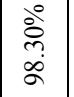 & छे & $\stackrel{\circ}{\circ}$ & $\begin{array}{l}\text { 今े } \\
\text { ले } \\
\infty \\
\alpha\end{array}$ & ळे & ळे & $\begin{array}{l}\text { 今े } \\
\text { هें } \\
\stackrel{0}{0}\end{array}$ & $\stackrel{\circ}{\circ}$ & ठ̊ํํ & ڤ̊ํ \\
\hline 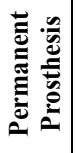 & 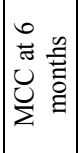 & 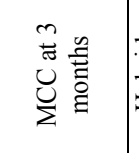 & 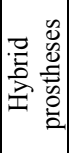 & 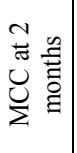 & 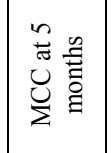 & & 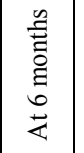 & 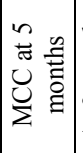 & 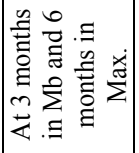 & & 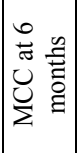 & 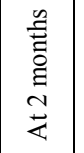 \\
\hline 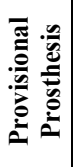 & 魚 & 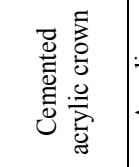 & 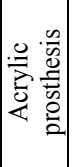 & 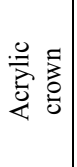 & 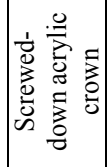 & 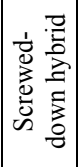 & 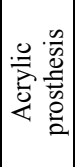 & $\mid$ & 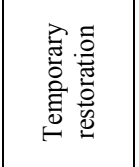 & 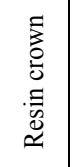 & 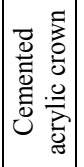 & 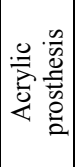 \\
\hline 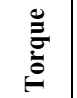 & ' & 离. & 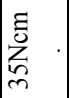 & ' & ' & 竎 & ' & 总 & ' & & 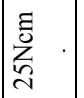 & 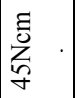 \\
\hline$\sum_{\substack{E \\
\Sigma}}^{e}$ & $\begin{array}{l}\sum_{n}^{0} \\
\substack{x \\
\sum_{m}^{m} \\
=}\end{array}$ & $\sum_{\check{\Sigma}}^{\star 凶}$ & $\sum_{\Sigma}^{\frac{\varkappa}{\Sigma}}$ & 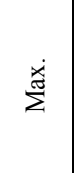 & 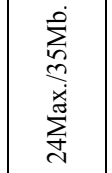 & $\dot{\Sigma}$ & 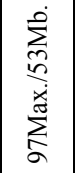 & ' & $\sum_{\Sigma}^{*}$ & $\stackrel{\dot{\varpi}}{\stackrel{\dot{\varpi}}{\Sigma}}$ & $\sum_{\Sigma}^{\frac{*}{\sigma}}$ & \\
\hline 童 & $\stackrel{2}{z}$ & z & $\underbrace{\infty}_{0}$ & ' & ' & 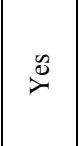 & $\underbrace{\infty}_{\nu}$ & $y^{3}$ & 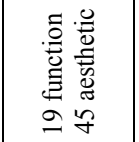 & & $\nu_{\nu}^{\infty}$ & $\overbrace{\nu}^{\infty}$ \\
\hline త్ & z & 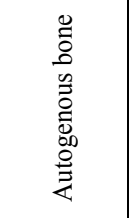 & 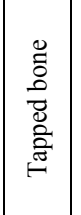 & ' & ' & 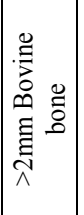 & 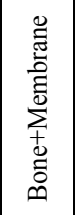 & 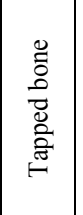 & 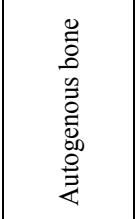 & 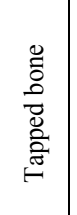 & ' & \\
\hline$\frac{\vec{\pi}}{\bar{x}}$ & $\gtrless$ & ż & $z$ & z & $\stackrel{\circlearrowright}{0}$ & $\stackrel{0}{\nu}$ & $\stackrel{0}{\nu}$ & $\stackrel{z}{z}$ & 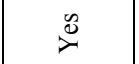 & $\underbrace{}_{\nu}$ & $\overrightarrow{i n}$ & $\dot{z}$ \\
\hline 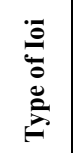 & ' & 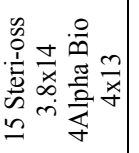 & 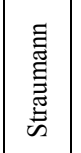 & $\Xi$ & ' & $\sum_{\stackrel{\oplus}{\infty}}$ & $\begin{array}{l}\frac{5}{0} \\
\stackrel{0}{\oplus} \\
\stackrel{\widetilde{E}}{<}\end{array}$ & ' & $\begin{array}{l}\dot{m} \\
\overline{0} \\
\stackrel{0}{0}\end{array}$ & 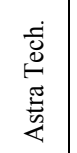 & 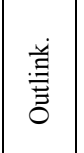 & $\begin{array}{l}\text { 离 } \\
\text { 具 }\end{array}$ \\
\hline $\begin{array}{l}\dot{0} \\
\dot{\theta}\end{array}$ & $\infty$ & 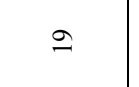 & $\therefore$ & $\infty$ & సి & in & in & $\stackrel{8}{n}$ & t & g & 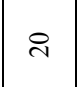 & $\tilde{n}$ \\
\hline 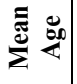 & fo & F & 8 & r & F & तె & 8 & in & $\stackrel{\infty}{n}$ & 8 & gे & $\stackrel{i n}{n}$ \\
\hline 苟 & $\begin{array}{l}\text { ro } \\
\text { o } \\
\text { ot } \\
\text { ב }\end{array}$ & $\begin{array}{l}\text { ro } \\
\text { o } \\
\text { +ㅏㅁ } \\
=\end{array}$ & $\frac{\text { so }}{\stackrel{2}{a+1}}$ & $\begin{array}{l}\text { ro } \\
\tilde{N} \\
\text { o+ } \\
\text { nn }\end{array}$ & $\begin{array}{l}\text { io } \\
\text { in } \\
\text { o+ } \\
\text { n- }\end{array}$ & $\begin{array}{l}\text { ro } \\
\stackrel{0}{\circ} \\
\text { o+ } \\
\end{array}$ & $\begin{array}{l}\text { ᄋ+ } \\
\stackrel{9}{9}\end{array}$ & $\begin{array}{l}\text { in } \\
\text { In } \\
\text { ot } \\
\text { nt }\end{array}$ & ' & $\begin{array}{l}\stackrel{5}{2} \\
\stackrel{2}{2} \\
\frac{2}{a}\end{array}$ & $\begin{array}{l}\text { ro } \\
\text { o } \\
\text { O+ } \\
\text { İ }\end{array}$ & ' \\
\hline 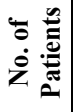 & $\stackrel{\infty}{\stackrel{2}{n}}$ & $=$ & 2 & $\infty$ & तิ & $\tilde{\lambda}$ & ㅇ & $\bar{\sim}$ & f & $\stackrel{\sim}{\sim}$ & సิ & 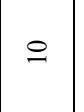 \\
\hline 离 & 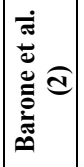 & 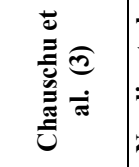 & 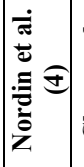 & 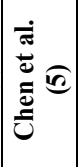 & 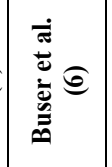 & 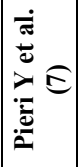 & 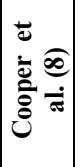 & 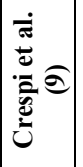 & 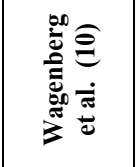 & 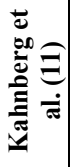 & 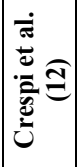 & 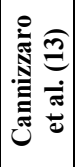 \\
\hline
\end{tabular}


Table 2. Study of the failed implants.

\begin{tabular}{|c|c|c|c|c|c|}
\hline Authors & $\begin{array}{l}\text { No. of } \\
\text { IOI }\end{array}$ & Location & Period & Cause & Treatment \\
\hline Barone et al. (2) & 1 & Maxilla & $\begin{array}{l}\text { Within first } \\
\text { month }\end{array}$ & Periimplantitis & Explant \\
\hline Chauschu et al.(3) & 3 & Maxilla & $\begin{array}{l}\text { One month } \\
\text { after surgery }\end{array}$ & $\begin{array}{l}\text { Pain, mobility and } \\
\text { suppuration }\end{array}$ & Explant \\
\hline Nordin et al.(4) & 2 & $?$ & At 30 months & $\begin{array}{l}\text { Fracture of the } \\
\text { platform }\end{array}$ & Explant \\
\hline Pieri et al.(7) & 1 & $?$ & $\begin{array}{l}\text { During the } \\
\text { first year }\end{array}$ & Poor bone quality & Explant \\
\hline Wagenberg et al.(10) & 2 & Mandible & - & Lack of integration & Explant \\
\hline Cannizzaro et al.(13) & 2 & Mandible & At 2 months & Mobility and pain & Explant \\
\hline
\end{tabular}

No. of IOI - number of implants.

DISTRIBUTION ACCORDING TO

PLACEMENT

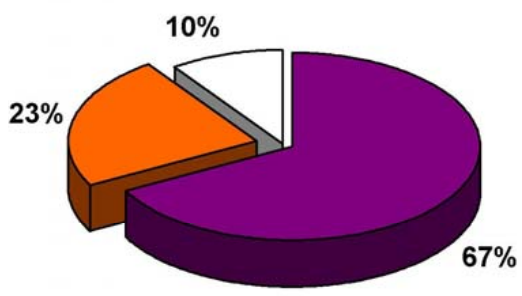

Fig. 1. Location of the implants.

\begin{tabular}{|l|}
$\square$ Maxilla \\
$\square$ Jaw \\
$\square ?$
\end{tabular}

$\square$ Jaw

DISTRIBUTION ACCORDING TO THE GAP FILLING

350

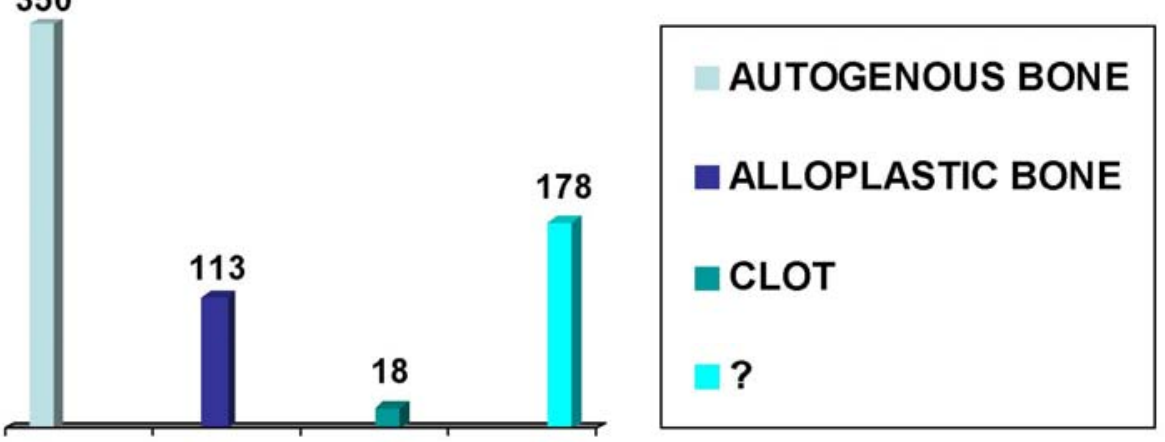

Fig. 2. Distribution of the implants according to filling of the GAP. 


\section{DISTRIBUTION ACCORDING TO THE IMMEDIATE LOADING}

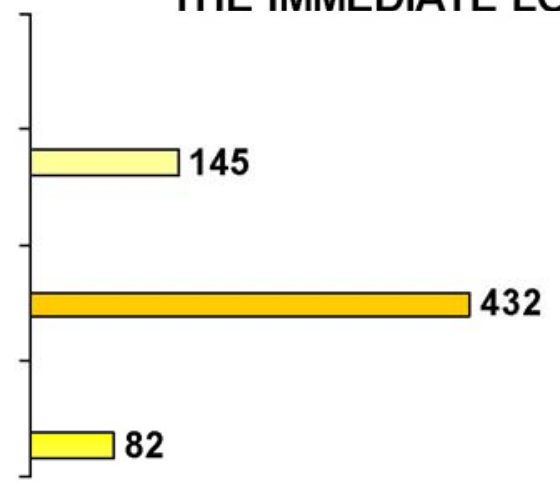

\begin{tabular}{|l|}
\hline$\square ?$ \\
$\square$ FUNCTION \\
$\square$ ESTHETIC \\
\hline
\end{tabular}

Fig. 3. Distribution of the implants according to the type of load withstood.

\section{Discussion}

In the surgical technique for the placement of the IPI, one may opt for either making an incision and detachment or for a flapless surgery. When performing an open technique, the blood supply from the periosteum is limited. Not lifting the flap for insertion of the implant and performing the surgery through the alveolus enables maintaining such vascularization intact, which leads to better post-operative recovery and healing. Current techniques plan for a flapless surgery when there is a gingival margin aligned correctly and an adequately keratinized gingiva; however, when it is found to be difficult to perform an extraction without traumatism to the hard or soft tissues, it becomes necessary to make an incision and detachment of a flap.

In our analysis, the number of authors who performed a closed technique as opposed to an open technique was six to six. Thus, for example, Barone et al. (2), Chauschu et al. (3), Nordin et al. (4), Chen et al. (5) and Crespi et al. (9) chose the first option and Pieri et al. (7), Cooper et al. (8), Buser et al. (6), Wagenberg et al. (10) and Kahnberg et al. (11) opted for the second technique, all of them obtaining a survival rate of $100 \%$ in their treatments.

There is a consensus among all of the authors, who agree that an extraction must be performed as carefully as possible, avoiding any stress placed on the vestibular cortical. Once the extraction has been performed, a meticulous curettage of the alveolus must be carried out in order to eliminate the remains of periodontal ligament and granulation tissue. There is also a consensus that during the drill sequence for inserting the IPI, the burs must lean against the palate in order to avoid fenestrations of the buccal wall and to improve the emergence profile.

Many authors mention the appearance of GAP as one of the most common situations during placement of the
IPI, although there is a debate about whether or not to proceed with osseous filling either with the autogenous bone, alloplastic or with membranes. Of the articles that included this data, Chauschu et al. (3), Nordin et al. (4), Crespi et al. (12), Cooper et al. (8), Wagenberg et al. (10) and Kahnberg et al. (11) used autogenous bone obtained from the tapping in order to fill in the gaps between the bone and the surface of the implant, whereas only Pieri et al. (7) opted for bovine bone, and Barone et al. (2) preferred that the clot fill the GAP. Regardless of the therapeutic option chosen, the success rate of the treatments ranged from $82 \%$ to $100 \%$.

Avoiding immediate loading for a period of three to six months has long been considered a necessary condition in order to achieve osseointegration. In recent years, there has been an increase in the number of studies on immediate loading which present in their conclusions a high success rate for their implant treatments. All of the authors reviewed placed immediate load on the implants inserted immediately after extraction, but some did so for aesthetic and other reasons, including function, such as Nordin et al. (4), Pieri et al. (7), Cooper et al. (8), Wagenberg et al. (10), Crespi et al. $(9,12)$ and Cannizzaro et al. (13), who did not eliminate the contacts during the maximum intercuspidation, obtaining success rates above $89 \%$. In analyzing the causes of failure in the 11 implants that did not integrate and in those that required performing an explant, there was no evidence that it was related to the placement or immediate loading of the implant.

\section{References}

References with links to Crossref - DOI

1. Calvo Guirado JL, Ortiz Ruiz AJ, Gómez Moreno G, López Marí L, Bravo González LA. Immediate loading and immediate restoration in 105 expanded-platform implants via the Diem System after a 16-month follow-up period. Med Oral Patol Oral Cir Bucal. 2008;13:E576-81.

2. Barone A, Rispoli L, Vozza I, Quaranta A, Covani U. Immediate 
restoration of single implants placed immediately after tooth extraction. J Periodontol. 2006;77:1914-20.

3. Chaushu G, Chaushu S, Tzohar A, Dayan D. Immediate loading of single-tooth implants: immediate versus non-immediate implantation. A clinical report. Int J Oral Maxillofac Implants. 2001;16:26772.

4. Nordin T, Graf J, Frykholm A, Helldén L. Early functional loading of sand-blasted and acid-etched (SLA) Straumann implants following immediate placement in maxillary extraction sockets. Clinical and radiographic result. Clin Oral Implants Res. 2007;18:441-51.

5. Chen ST, Darby IB, Reynolds EC, Clement JG. Immediate implant placement postextraction without flap elevation. J Periodontol. 2009;80:163-72.

6. Buser D, Halbritter S, Hart C, Bornstein MM, Grütter L, Chappuis $\mathrm{V}$, et al. Early implant placement with simultaneous guided bone regeneration following single-tooth extraction in the esthetic zone: 12 -month results of a prospective study with 20 consecutive patients. J Periodontol. 2009;80:152-62.

7. Pieri F, Aldini NN, Fini M, Corinaldesi G. Immediate occlusal loading of immediately placed implants supporting fixed restorations in completely edentulous arches: a 1-year prospective pilot study. J Periodontol. 2009;80:411-21.

8. Cooper LF, Rahman A, Moriarty J, Chaffee N, Sacco D. Immediate mandibular rehabilitation with endosseous implants: simultaneous extraction, implant placement, and loading. Int J Oral Maxillofac Implants. 2002;17:517-25.

9. Crespi R, Capparè P, Gherlone E, Romanos GE. Immediate occlusal loading of implants placed in fresh sockets after tooth extraction. Int J Oral Maxillofac Implants. 2007;22:955-62.

10. Wagenberg B, Froum SJ. A retrospective study of 1925 consecutively placed immediate implants from 1988 to 2004. Int J Oral Maxillofac Implants. 2006;21:71-80.

11. Kahnberg KE. Immediate implant placement in fresh extraction sockets: a clinical report. Int J Oral Maxillofac Implants. 2009;24:282-8.

12. Crespi R, Capparé P, Gherlone E, Romanos GE. Immediate versus delayed loading of dental implants placed in fresh extraction sockets in the maxillary esthetic zone: a clinical comparative study. Int J Oral Maxillofac Implants. 2008;23:753-8.

13. Cannizzaro G, Leone M, Esposito M. Immediate functional loading of implants placed with flapless surgery in the edentulous maxilla: 1-year follow-up of a single cohort study. Int J Oral Maxillofac Implants. 2007;22:87-95. 